\title{
ANALYSIS DETERMINANT OF DIVIDEND PAYOUT RATIO AND ITS IMPACT TO THE FIRM VALUE (EMPIRICAL STUDY ON FOOD AND BEVERAGE INDUSTRY ISSUER 2016-2019)
}

\author{
M. Noor Salim $1 \rrbracket$, Syifa Aulia $2 \square$ (iD) \\ Mercu Buana University, Indonesia \\ 2 ibis Styles Hotel Jatibening, Indonesia
}

Received 01 August 2021

Accepted 16 August 2021

Published 30 September 2021

\section{CorrespondingAuthor}

M. Noor Salim, m_noorsalim@gmail.com DOI 10.29121/ijetmr.v8.i9.2021.1017

Funding: This research received no specific grant from any funding agency in the public, commercial, or not-for-profit sectors.

Copyright: (C) 2021 The Author(s). This is an open access article distributed under the terms of the Creative Commons Attribution License, which permits unrestricted use, distribution, and reproduction in any medium, provided the original author and source are credited.

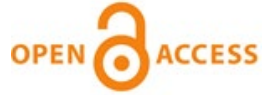

\section{ABSTRACT}

The purpose of this research is to Analyze Determinant of Dividend Payout Ratio and Its Impact to The Firm Value (Empirical Study on Food And Beverage Industry Issuer 2016-2019). The samples in the form of secondary data as many as 16 companies collected from financial statements listed on the Indonesia Stock Exchange (IDX). In this study, nine research hypotheses were formulated. The analysis design used is quantitative data with panel data regression method which is processed with Eviews 9 with a random effect model. Hypothesis testing using F test, T test, and Sobel test (Path Analysis). The results showed in direct financial performance as proxied by the current ratio, debt equity ratio and return on assets had a positive affect on firm value, and partially current ratio, debt equity ratio and return on assets had a positive affect on dividend payout ratio. Directly, current ratio, debt equity ratio and return on assets have a positive affect on firm value. Indirectly, the dividend payout ratio is able to strengthen the relationship between the current ratio, debt equity ratio and return on assets to firm value.

Keywords: Liquidity, Solvency, Profitability, Dividend Payout Ratio, Firm Value

\section{INTRODUTION}

Firm value can be said is a picture of investors about the level of success of a company, where the value of the company often reflected in the company's stock price. The positive relationship between the stock price of a company and firm value shows of the increase in stock price and followed by the increase in the firm value and otherwise. However, if firm value is higher, public's can be trust and prospect to the company in the future will also increase.

An investor often dealing with the risks and uncertainties that difficult to predict. For to the minimize of this, investors need different information all that deals with the company, all the internal factor which is a company financial performance and other external factors such as other information, for example economic and political condition of a country or region. Information about the performance of a company can usually be obtained through the financial report company including information about profit and dividend produced every piece of the company shares issued. Based on that information then investors will have an overview of the company. Each company has a policy that has been determined, dividend payment but all the shareholders of course want the payment of dividends that is certain and stable. 
Stable dividends will reduce the uncertainty of the results of investment that they do. The low uncertainty of the investment will increase public trust in the company, the value of the company and the price stocks will also be increased. However, to achieve this, the company requires sales volume and profit for a nominal stable in order to produce dividends are high. The greater the volume of sales and profit is nominal it is expected that the greater to the determinant of the dividend of the company to the shareholders.

This is done in order to avoid losses and the most important thing is that the return or rate of return of shares in accordance with the expectations of investors. The company's financial performance often becomes a measurement tool of investors to take investment decisions. Every investor has the emphasis is different to the items of the financial statements. Benchmark the company's performance can be measured and determined based on the financial ratios of the company. Company's financial ratios can be found in the company's financial statements in the form of accounting information that can be used one as a base of information to take an investment decision. Investors who do fundamental analysis of the information about the financial performance of the company's internal with this information ( Kurrohman et al.(2014)). Financial ratios are mostly used as reference in view the performance of a company is the ratio of liquidity, solvency, and profitability.

Development of the Average Dividend Payout Ratio Industry Groups which are listed in Indonesia stock Exchange year 2016 -2019 (in percent)

\begin{tabular}{|c|l|r|r|r|r|}
\hline \multirow{2}{*}{ No } & \multirow{2}{*}{$\begin{array}{c}\text { Industrial Group } \\
\text { (Consumer Goods) }\end{array}$} & \multicolumn{4}{|c|}{ Dividend Payout Ratio } \\
\cline { 3 - 6 } & \multicolumn{1}{|c|}{2016} & \multicolumn{1}{c|}{2017} & \multicolumn{1}{c|}{2018} & \multicolumn{1}{c|}{2019} \\
\hline 1 & Food \& Beverage & 1.513 & 3.057 & 2.709 & 2.477 \\
\hline 2 & Cosmetics & 7.007 & 6.859 & 10.549 & 8.394 \\
\hline 3 & Tobacco & 9.591 & 11.117 & 8.331 & 6.488 \\
\hline 4 & pharmacy & 6.786 & 6.221 & 5.005 & 3.592 \\
\hline 5 & Houseware & 4.570 & 2.219 & 9.969 & 4.490 \\
\hline Rata-Rata Per Tahun & 5.894 & 5.894 & 7.313 & 5.088 \\
\hline
\end{tabular}

From tabel that known level development of the average Dividend Payout Ratio (DPR) each of the industrial sector in Indonesia stock Exchange (BEI) in the year 2016-2019 experiencing fluctuations and do not indicate the presence of the application of a stable dividend policy in the sector of the food and beverage industry especially in the food and beverage industry which became the object of research. Dividend policy is one of the important decisions for the company, because the policy is related to the decision of the company in determining the magnitude of the net profit will be distributed as dividends and how much profit to be reinvested into the company in the form of retained earnings (retairned earnings). In addition, the dividend policy to be an important part of the strategy of long-term financing of the company in responding to the dynamics of the business environment. This can show the problem of determinants of the dividend policy. 


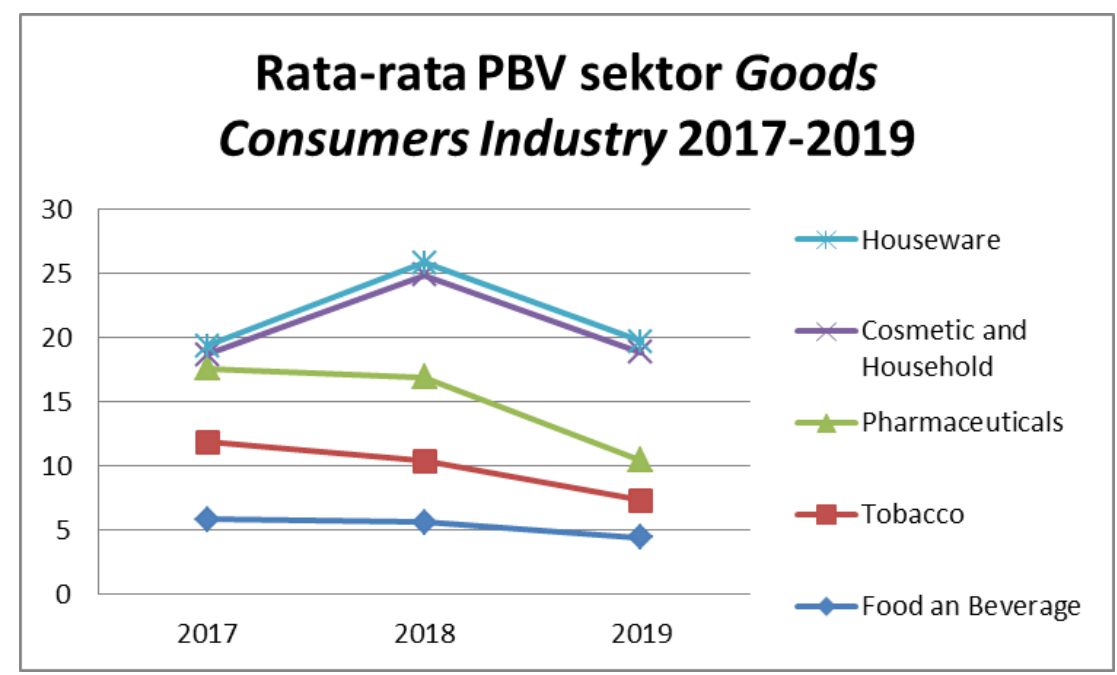

Average PBV in goods company industry listed on BEI 2016-2019

Source : Central Bureau Of Statistics 2020

The value of average in sector of goods consumers industry in each sub-sector has increased and decreased normal. However on the sub-sector of houseware and cosmetics and household increases the value of PBS drastically during the year 2018 and also again on the decline during the year 2019. While other can we know the sub-sector of the pharmaceutical, tobacco industry, and also food and drinks, the value of PBV decreased every year. However, in between all sectors of industrial parts, offered food and beverage is the sector of industry that has a value of PBV is the most stable. This is because the value of PBV in the food and beverage industry decrease is not significant. With it, the author can conclude that the food and beverage industry, namely industrial sectors that have a level of stability which is good compared with the industry on the other sub-sector industry.

So therefore, with the phenomenon of the determinants of dividend payments that fluctuate every year. This will have an impact on investor interest in investing in the company and also the number of firms industry Food and Beverage Industry is likely to decline during the years 2016 to 2019, and also the value of the company Food and Beverage Industry sector tends to decrease during the year 2016 up to 2019 but it is precisely volume sale of the company Food and Beverage industry is likely to increase in the period 2016 to 2019 that have an effect on the liquidity, solvency and profitability.

\section{LITERATURE REVIEW}

The agency theory perspective is the basis used to understand the issue of dividend payout ratio determinants and firm value. Agency theory results in an asymmetric relationship between the principal (investor) and manager (agent), to avoid this asymmetry relationship, it is necessary to clarify the dividend payout ratio in dividend policy which aims to assist investors in making stock investment decisions because it is related to the quantity of return generated. The relationship between agency theory and firm value is because in the agency relationship there is 
a conflict of interest between the agent and the principal. So financial performance which includes liquidity, solvency and profitability is needed by investors to see the quality of a company before making an investment.

\subsection{SIGNALING THEORY}

Signaling theory explain about a boost company so that the company provide information about the condition of financial statements better for parties from both external and internal company. Such encouragement appears due to the presence of asymetry of information between external parties and the management of the company. Asymetry of information caused by the company find out more information about the company's prospects, risks that may arise and how the condition of the actual company, compared with external parties or potential investors (Suryono, 2019).

\subsection{FIRM VALUE}

According from Birgham (1977) in (Metha and Gunawan (2011)), all companies have a primary goal in improving the value of the company, this effort was carried out to enhance the prosperity of the politics of shareholders. The value of the company is an important aspect of a company, this is because as the rising value of the company, prosperity and also the well-being of the shareholders will be increased as well.

$$
\text { Price book value }=\frac{\text { harga Saham }}{\text { nilai buku }}
$$

\subsection{FINANCIAL RATIO}

Financial ratio defined as a ratio calculation using the reports from financial companies to measure and assess the financial condition and performance of a company (Hery (2016)). With this ratio, investors can determine the level of health and condition of the company at this time. In this study financial ratio used is liquidity, solvency, and profitability.

Liquidity ratio using for determine the liquidity of a company and the ability in pay short-term debt see with current assets of the company against the debt current. As for the liquidity ratio that researchers use in this study are current ratio (CR). The Current ratio is the ratio used to measure a company's ability to meet short term liabilities that will be due soon on all current assets that are owned by the company (Hery (2016)). This ratio is assumed by the study as the ratio of the right to represent the liquidity ratio. So, formula calculation of current ratio:

$$
\text { current ratio }=\frac{\text { current asset }}{\text { curretn liabilities }} \times 100 \%
$$

Solvency ratio is the ratio that used for measure a company's ability to manage debt to profit, and also to pay back the debt. Researchers using the debt to equity ratio (DER) to measure the solvency ratio in this study. DER is a ratio that measures 
a company's ability to repay the debt capital owned. Analysis (2011) stated that if the company's assets are obtained from the debt will have an impact on the increase of investment risk. If the company is unable to pay off its obligations according to the time that has been determined. Thus, this ratio will have an impact on the value of a company. So, formula calculation of debt to equity ratio:

$$
\text { Debt to equity ratio }=\frac{\text { total debt }}{\text { total capital }} \times 100 \%
$$

The last is profitability ratio that researchers use in this study is Return on Assets (ROA). ROA is used to see the magnitude of the return of investment has been invested by the investor. So that it is relevant to the purpose of the investment made by investors in the Capital Market (Fahmi(2013)). So, formula calculation of return on assets:

$$
\text { Return on assets }=\frac{\text { net income }}{\text { total asset }} \times 100 \%
$$

\subsection{DIVIDEND PAYOUT RATIO}

The main purpose of the investment made by the investor to the company certain is to get the return. On the other hand, with the investment of the investors, the company also expects to continue to survive and develop their business. Return expected investors can be in the form of capital gains or dividend income (Ulfa and Yuniati (2016)). Stock Return proxies by the Dividend payout ratio, where the value of the house of representatives is obtained by dividing the value of the annual dividend with an annual dividend or by dividing the value of the earnings of a building stock with dividend shares/sheet (Ulfa and Yuniati (2016)). Level of dividend payout ratio can also be affected by the company's financial performance. Then, the dividend policy will affect the value of the company. So, the variable dividend policy is also often referred to as a signal to investors in assessing the condition of the company. So, formula calculation of dividend payout ratio:

$$
\text { Devidend Payout Ratio }=\frac{\text { Dividend per share }}{\text { Earning per share }} \times 100 \%
$$

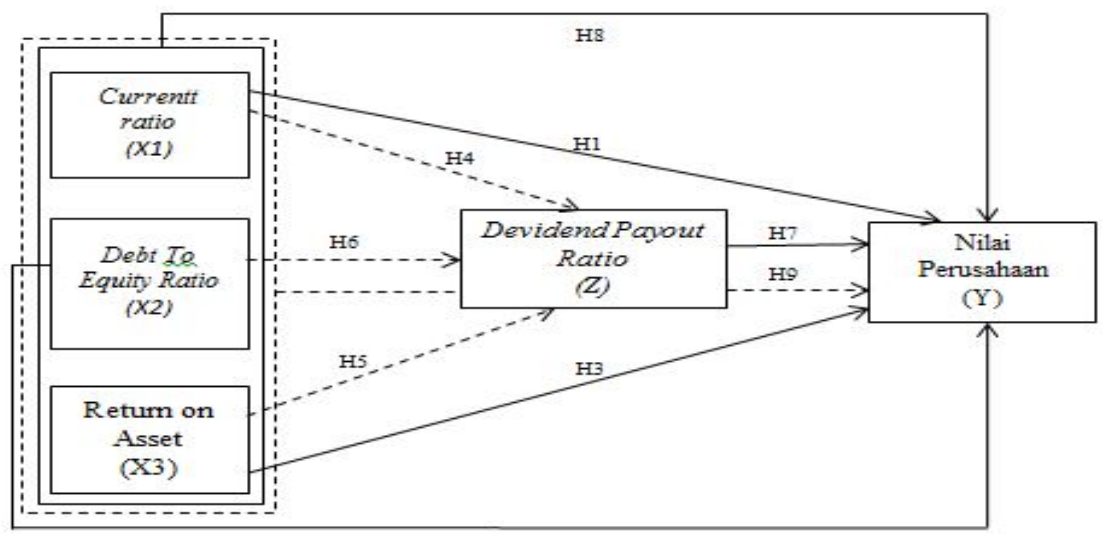




\section{Hypothesis :}

H1 : Current Ratio (CR) has positive impact on the firm value.

H2 : Debt To Equity Ratio (DER) has positive impact on the firm value.

H3 : Return On Assets (ROA) has positive impact on the firm value.

H4 : Current Ratio (CR) has positive impact on the dividend payout ratio

H5 : Debt To Equity Ratio (DER) has positive impact on the dividend payout ratio.

H6 : Return On Assets (ROA) has positive impact on the dividend payout ratio.

H7 : Dividend Payout Ratio (DPR) has positive impact on the firm value.

H8 : Current Ratio, Debt To Equity Ratio, Return On Assets simultaneously has positive impact on the firm value.

H9 : Current Ratio, Debt To Equity Ratio, Return On Assets simultaneously has positive impact through dividend payout ratio on the firm value.

\section{MATERIALS AND METHODS}

\subsection{POPULATION AND SAMPLE}

The population in this research was 30 companies that listed in the annual financial statements of the company food and beverage industry in Indonesia stock Exchange. Samples were taken by purposive sampling technique and then obtained the 16 companies that deserve to be used as research sample. The research period is from 2016 to 2019 with a total observation research is 64 .

\subsection{DATA TYPE AND SOURCE}

Data used in this research is taken from secondary data sources. The financial statements obtained from the website of the Indonesia Stock Exchange website.

\subsection{DATA ANALYSIS METHOD}

The analytical method used on this research was quantitative and descriptive statistics with regression of panel data, data proceed using Eviews 9 analysis of the data with the data type of the cross-section data and time-series. There are several techniques used in the data panel, such as the Ordinary Least Square Pooled (Common Effect Model), the Fixed Effect Model (FEM), Random Effect Model (REM). The method used model of panel data that are most appropriate fot this research is Chow test, Hausman test, and Lagrange Multiplier test. 


\section{RESULTS AND DISCUSSION}

\subsection{DESCRIPTIVE STATISTIC}

\section{Descriptive Statistics}

\begin{tabular}{|c|c|c|c|c|c|c|}
\hline \multicolumn{7}{|c|}{ Deskriptif Statistik } \\
\hline & $\mathbf{N}$ & Minimum & Maximum & Mean & Median & $\begin{array}{c}\text { Std } \\
\text { Deviation }\end{array}$ \\
\hline CR & 64 & 0.212085 & 8.637842 & 2.34375 & 1.698027 & 1.89025 \\
\hline DER & 64 & 0.065126 & 2.899874 & 0.513011 & 0.473568 & 0.484653 \\
\hline ROA & 64 & -2.640992 & 0.431697 & 0.063344 & 0.513011 & 0.370896 \\
\hline PBV & 64 & -6.933604 & 2.726337 & 5.689467 & 2.286294 & 3.7869503 \\
\hline DPR & 64 & 0.000324 & 0.097568 & 0.033559 & 0.025276 & 0.028666 \\
\hline
\end{tabular}

Source: The results of the data processed with Eviews 9

\subsection{PANEL DATA REGRESSION RESULT}

The first model in estimating panel data regression. On the model of the estimation of panel data, there are three techniques that can be used, such as Ordinary Least Square (OLS), Fixed Effects Model and Random Effect Model. From chow test and hausman the most suitable model chosen is Random Effect.

\subsubsection{REGRESSION EQUATION MODEL 1}

After testing the regression model of panel data has determined that random effect model the most suitable model chosen for use in this research. Here is the results of a panel data random effect model.

\section{Regression Equation Model 1}

\begin{tabular}{|c|c|c|c|c|}
\hline \multicolumn{5}{|c|}{$\begin{array}{l}\text { Dependent Variable: PBV } \\
\text { Method: Panel Least Squares } \\
\text { Date: } 07 / 25 / 21 \quad \text { Time: } 20: 17 \\
\text { Sample: } 20162019 \\
\text { Periods included: } 4 \\
\text { Cross-sections included: } 16 \\
\text { Total panel (balanced) observations: } 64\end{array}$} \\
\hline Variable & Coefficient & Std. Error & t-Statistic & Prob. \\
\hline C & 703.4209 & 249.9097 & 2.814700 & 0.0072 \\
\hline CR & 52.36696 & 72.32120 & 0.724089 & 0.4728 \\
\hline DER & 26.73581 & 243.8565 & 0.109637 & 0.0192 \\
\hline ROA & 9.601665 & 170.6278 & 0.056273 & 0.0344 \\
\hline \multicolumn{5}{|l|}{ Cross-section fixed } \\
\hline R-squared & 0.777637 & \multicolumn{2}{|c|}{ Mean dependent var } & 567.5783 \\
\hline Adjusted R-squared & 0.688692 & \multicolumn{2}{|c|}{ S.D. dependent var } & 703.1804 \\
\hline S.E. of regression & 392.3395 & \multicolumn{2}{|c|}{ Akaike info criterion } & 15.02366 \\
\hline Sum squared resid & 6926863. & \multicolumn{2}{|c|}{ Schwarz criterion } & 15.66458 \\
\hline Log likelihood & -461.7572 & \multirow{2}{*}{\multicolumn{2}{|c|}{$\begin{array}{l}\text { Hannan-Quinn criter. } \\
\text { Durbin-Watson stat }\end{array}$}} & 15.27615 \\
\hline F-statistic & 8.742876 & & & 2.250756 \\
\hline Prob(F-statistic) & 0.000000 & \multicolumn{2}{|c|}{ Durbin-Watson stat } & \\
\hline
\end{tabular}




\section{A. Regression Results}

$$
\mathrm{PBV}=703.4209+52.36696 * \mathrm{CR}+26.73581 * \mathrm{DER}+9.601665^{*} \mathrm{ROA}
$$

\section{B. Hypothesis Test Results}

- Coefficient of Determination (R2)

Adjusted R-squared value of 0.777637 or $77.7637 \%$ means that the firm value variable can be explained by independent variables, namely Current Ratio, Debt Equity Ratio, and Return on Assets while the remaining $22.236 \%$ is explained by other factors outside the research model.

- F-Test

The result for the probability F-statistic is 0.000 which is smaller than the 0.05 significance level. That is, the Current Ratio, Debt Equity Ratio, and Return on Assets simultaneously have a significant effect on firm value.

- Partial Significance Test (T-Test)

With $=5 \%$, df $(n-k)=59$, then the value of $\mathrm{T}$ table is 2.00099 . The results for each variable can be explained as follows:

1) The t-statistic CR value $(0.724089)<\mathrm{t}$ table 2.00099 and the probability value is $0.4728>0.05$, meaning that there is no direct partial effect between the $\mathrm{CR}$ variables on the $\mathrm{PBV}$ variable.

2) DER t-statistic value $(0.109637)<t$ table (2.00099) and the probability value is $0.0192<0.05$, meaning that it has a positive influence between the DER variable on the PBV variable partially directly

3) The value of t-statistic ROA $(0.056273)<t$ table (2.00099) and the probability value is $0.0344<0.05$, meaning that it has a positive influence between the ROA variables on the PBV variable partially directly

\subsubsection{REGRESSION EQUATION MODEL 2}

\section{Regression Equation Model 2}

\begin{tabular}{|c|c|c|c|c|}
\hline \multicolumn{4}{|c|}{ Dependent Variable: DPR } & \\
\hline \multicolumn{5}{|c|}{ Method: Panel Lesst Squares } \\
\hline \multicolumn{5}{|c|}{ Date: $09 / 06 / 21$ Time: $23: 55$} \\
\hline \multicolumn{5}{|l|}{ Sample: 20162019} \\
\hline \multicolumn{5}{|l|}{ Periods included: 4} \\
\hline \multicolumn{5}{|c|}{ Cross-sections included: 16} \\
\hline \multicolumn{5}{|c|}{ Total panel (balanced) observations: 64} \\
\hline Variable & Coefficient & Std. Erroi & t-Statistic & Prob. \\
\hline C & 5.036625 & 0.017905 & 2.045475 & 0.0467 \\
\hline CR & 3.900679 & 0.005199 & 0.130512 & 0.0296 \\
\hline DER & 2.102160 & 0.017649 & 0.122375 & 0.0403 \\
\hline ROA & 4.306692 & 0.013497 & 0.495821 & 0.0324 \\
\hline \multicolumn{5}{|c|}{ Effects Specification } \\
\hline \multicolumn{5}{|c|}{ Cross-section foxed (dummy variables) } \\
\hline R-squared & 0.309232 & \multicolumn{2}{|c|}{ Mean dependent var } & 0.033559 \\
\hline Adjusted R-squared & 0.032924 & \multicolumn{2}{|c|}{ S.D. dependent var } & 0.028666 \\
\hline S.E. of regression & 0.028190 & \multicolumn{2}{|c|}{ Aka ike info criterion } & 4.058145 \\
\hline Sum squared resid & 0.035761 & \multicolumn{2}{|c|}{ Schwarz criterion } & 3.417226 \\
\hline Log likelihood & 148.8606 & \multirow{2}{*}{\multicolumn{2}{|c|}{$\begin{array}{l}\text { Hannan-Quinn criter. } \\
\text { Durbin-Watson stat }\end{array}$}} & 3.805654 \\
\hline F-statistic & 1.119158 & & & 3.039022 \\
\hline Prob(F-statistic) & 0.366244 & & & \\
\hline
\end{tabular}




\section{A. Regression Results}

$\mathrm{DPR}=5.036625+3.900679 * \mathrm{CR}+2.102160 * \mathrm{DER}+4.306692 * \mathrm{ROA}$

\section{B. Hypothesis Test Results}

- Coefficient of Determination (R2)

Adjusted R-squared value of 0.309232 or $30.9232 \%$ means that the mediating variable Dividend Payout ratio can be explained by independent variables, namely Current Ratio, Debt Equity Ratio, and Return on Assets while the remaining 69,0768 $\%$ is explained by other factors outside the research model.

- F-Test

The result for the probability F-statistic is 0.366244 which is biger than the 0.05 significance level. That is, the increase in DPR is not always influenced by the company's performance simultaneously, namely the variables CR, DER, ROA.

- Partial Significance Test (T-Test)

With $=5 \%$, df $(n-k)=59$, then the value of $\mathrm{T}$ table is 2.00099 . The results for each variable can be explained as follows:

1) The t-statistic CR value $(0.130512)<\mathrm{t}$ table 2.00099 and the probability value is $0.0296<0.05$, meaning that there is a positive significant influence between the CR variable and the DPR variable partially.

2) The t-statistic value of DER (0.122375) < t table (2.00099) and the probability value of $0.0403<0.05$ means that there is a positive significant between the DER variable on the DPR variable partially.

3) The ROA t-statistic value (0.495821) > t table (2.00099) and the probability value is $0.0324<0.05$, meaning that there is a positive significant between the ROA variable on the DPR variable partially.

\subsubsection{REGRESSION EQUATION MODEL 3}

\section{Regression Equation Model 3}

\begin{tabular}{|c|c|c|c|c|}
\hline \multicolumn{5}{|c|}{\begin{tabular}{|l} 
Dependent Variable: PBV \\
Method: Panel Least Squares \\
Date: $07 / 25 / 21$ Time: $20: 35$ \\
Sample: 20162019 \\
Periods included: 4 \\
Cross-sections included: 16 \\
Total panel (balanced) observations: 64
\end{tabular}} \\
\hline Variable & Coefficient & Std. Error & t-Statistic & Prob. \\
\hline $\begin{array}{c}\mathrm{C} \\
\text { DPR } \\
\text { CR } \\
\text { DER } \\
\text { ROA }\end{array}$ & $\begin{array}{r}705.1795 \\
0.313737 \\
-53.62088 \\
-27.43631 \\
6.558865\end{array}$ & $\begin{array}{l}253.9029 \\
4.369438 \\
75.19023 \\
246.7905 \\
177.6735\end{array}$ & $\begin{array}{l}2.777359 \\
0.071803 \\
0.713136 \\
0.111172 \\
0.036915 \\
\end{array}$ & $\begin{array}{l}0.0080 \\
0.0019 \\
0.0047 \\
0.0020 \\
0.0307 \\
\end{array}$ \\
\hline \multicolumn{5}{|c|}{ Effects Specification } \\
\hline \multicolumn{5}{|c|}{ Effects Specification } \\
\hline \multicolumn{5}{|c|}{ Cross-section fixed (dummy variables) } \\
\hline $\begin{array}{l}\text { R-squared } \\
\text { Adjusted R-squared } \\
\text { S.E. of regression } \\
\text { Sum squared resid } \\
\text { Log likelihood } \\
\text { F-statistic } \\
\text { Prob(F-statistic) }\end{array}$ & $\begin{array}{r}0.876663 \\
0.681654 \\
396.7496 \\
6926051 \\
-461.7534 \\
8.099884 \\
0.000000\end{array}$ & \multicolumn{2}{|c|}{$\begin{array}{l}\text { Mean dependent var } \\
\text { S.D. dependent var } \\
\text { Akaike info criterion } \\
\text { Schwarz criterion } \\
\text { Hannan-Quinn criter. } \\
\text { Durbin-Watson stat }\end{array}$} & $\begin{array}{l}567.5783 \\
703.1804 \\
15.05479 \\
15.72945 \\
15.32057 \\
2.248682\end{array}$ \\
\hline
\end{tabular}




\section{A. Regression Results}

$$
\mathrm{Y}=705.1795+0.313737 * \mathrm{DPR}
$$

The t-statistic value of Dividend Payout Ratio on Price Book Value $(0.9431)<\mathrm{t}$ table 2.00099 and the probability value is $0.0019<0.05$, meaning that there is a significant influence between the Current Balance variable and stock return as a mediating variable.

\section{Analysis Sobel Test}

According (Ghozali (2018) in the (Akhmadi et al. (2020)) sobel test has testing the strength of the indirect effect of $\mathrm{X}$ to $\mathrm{Y}$ through $\mathrm{Z}$. The influence of mediation indicated by the multiplication coefficient (ab) need to be tested with the test Sobel as follows:

$$
\mathrm{Sab}=\sqrt{b^{2} s a^{2}+a^{2}} s b^{2}+s a^{2} s b^{2}
$$

With count t, as follows :

$$
z=\frac{\alpha b}{S a b}
$$

With hypotheses as follows:

Ho : $\beta=0$; No impact of Liquidity, Solvency, Profitability on Dividend Payout Ratio as a mediating variable to the firm value.

Ha : $\beta \neq 0$; Has impact of Liquidity, Solvency, Profitability on Dividend Payout Ratio as a mediating variable to the firm value.

\begin{tabular}{|c|c|c|c|c|}
\hline Uraian & Sob & Sab & t hitung & t tabel \\
\hline $\begin{array}{c}\text { Sobel Test 1 } \\
\text { Impact of Current Ratio on Dividend } \\
\text { Payout Ratio as a mediating variable on } \\
\text { firm value }\end{array}$ & 0.713136 & 75.19023 & 3.948426 & 2.00099 \\
\hline $\begin{array}{c}\text { sobel test 2 } \\
\text { Impact of Debt Equity Ratio on } \\
\text { Dividend Payout Ratio as a mediating } \\
\text { variable on Firm Value }\end{array}$ & 0.111172 & 246.7905 & 5.55472 & 2.00099 \\
\hline $\begin{array}{c}\text { sobel test 3 } \\
\text { Impact of Return on Asset on Dividend } \\
\text { Payout Ratio as a mediating variable on } \\
\text { Firm Value }\end{array}$ & 0.036915 & 177.6735 & 4.020775 & 2.00099 \\
\hline
\end{tabular}

Sobel test in this research using application from danielsoper.com that show the impact of the indirect Current Ratio on Firm Value mediated the Dividend Payout Ratio, the value of $t$ count is $3.948426<2.00099 \mathrm{t}$ table. The influence of indirect Debt Equity Ratio on Firm Value mediated the Dividend Payout Ratio, the value of $t$ count is $5.5547195>2.00099 t$ table. No direct influence of Return On Assets on Firm Value mediated the Dividend Payout Ratio, the value of $t$ count is $4.0207749>2.00099$ t table. 


\section{DISCUSSION}

1) Partially, Current Ratio has a negative effect on firm value, according to previous research from Salim and Susilowati (2020a) showing CR and asset growth have a significant negative effect on firm value. While solvency and profitability have a positive effect, according to research conducted by Anggraeni and Musaroh (2018), which shows that DER has a significant positive effect on firm value, and Salim and Firdaus (2020) also state that ROA has a significant positive effect on not significant effect on firm value.

2) There is a significant positive effect on the Dividend Payout Ratio on the Current Ratio, Debt Equity Ratio, and Return On Assets have a direct partial effect, according to research conducted by Gunawan and Adi (2018) showing that liquidity partially has a positive effect on policy dividends, and Akhmadi and Robiyanto (2020) said that DER had a significant effect on dividend policy, and Budagaga (2017) stated that there was a significant positive ROA relationship between dividend payments and firm value.

3) Directly Dividend Payout Ratio has a positive effect on firm value. This is in line with research conducted by Anton and Gabriel (2016). Dividend payout ratio has a positive effect on firm value. Indirectly, the current ratio, debt equity ratio, and return on assets can strengthen the relationship between the influence of firm value through the mediating variable, namely the dividend payout ratio. This proves that financial performance can describe the company's profit level to get a return that is used as a dividend policy which is expected to be distributed to shareholders, for that a good return will certainly strengthen the company's value in the eyes of investors and management.

\section{CONCLUSION}

In summary, the results of this study are as follows:

1) Current Ratio has a negative effect on firm value.

2) Debt Equity Ratio has a positive and significant effect on firm value.

3) Return on Assets has a positive and significant effect on firm value.

4) Current Ratio has a positive and significant effect on the dividend payout ratio.

5) Debt Equity Ratio has a positive and significant effect on the dividend payout ratio.

6) Return on Assets has a positive and significant effect on the dividend payout ratio.

7) Dividend payout ratio has a positive and significant effect on firm value.

8) Current Ratio, debt to equity ratio and return on assets have a positive and significant effect on firm value simultaneously.

9) Current Ratio, debt to equity ratio and return on Current Ratio have a positive and significant effect simultaneously through the Dividend Payout Ratio on firm value.

\section{RECOMENDATION}

This research is further expected to add to the variable external factors because the empirical findings it produces the value of R-square 0.876663 which means the 
independent variables used in this study can be explained $87.6 \%$ means that the dependent variable has a significant positive effect against an intervening variable, If add or use other factors that affect the determinants of dividend payout ratio and firm value not only on internal factors, but also added external factors, namely interest rates, inflation, exchange rate and economic growth, the possibility of the rest of $12.4 \%$ can explain the variation of the increase in R-square so that it can produce results that more research comprehensive.

\section{REFERENCES}

Akhmadi, Akhmadi, and Robiyanto Robiyanto (2020). "The Interaction Between Debt Policy, Dividend Policy , Firm Growth , and Firm Value." Journal of Asian Finance, Economics and Business 7(11):699-705. Retrieved from https://doi.org/10.13106/jafeb.2020.vol7.no11.699

Alenazi, Huda, and Bernard Barbour (2019). "The Relationship between Dividend Policy and Firm Value within Qatari Banks." Qscience Connect 2019(1):1-22. Retrieved from https://doi.org/10.5339/connect.2019.5

Analisa, Yangs (2011). "Pengaruh Ukuran Perusahaan, Leverage, Profitabilitas Dan Kebijakan Dividen Terhadap Nilai Perusahaan (Studi Pada Perusahaan Manufaktur Yang Terdaftar Di Bursa Efek Indonesia Tahun 2006-2008)." Universitas Diponegoro. Retrieved from http://eprints.undip.ac.id/29436/

Anggraeni, Rusandina, and Musaroh (2018). "Analisis Determinan Nilai Perusahaan Studi Pada Perusahaan Manufaktur Yang Terdaftar Di Bursa Efek Indonesia." Jurnal Manajemen Bisnis Indonesia 3:327-36. Retrieved from http://dx.doi.org/10.21831/jim.v15i2.34760

Anton, Sorin Gabriel (2016). "The Impact Of Dividend Policy On Firm Value . A Panel Data Analysis Of Romanian Listed Firms." Journal of Public Administration, Finance and Law (10):107-12. Retrieved from https://www.ceeol.com/search/article-detail?id=743810

Aprillianto, Bayu, Novi Wulandari, and Taufik Kurrohman (2014). "Perilaku Investor Saham Individual Dalam Pengambilan Keputusan Investasi: Studi Hermeneutika-Kritis." E-Journal Ekonomi Bisnis Dan Akuntansi 1 (1):16-31. Retrieved from https://doi.org/10.19184/ejeba.v1i1.567

Arieska, Metha, and Barbara Gunawan (2011). "Pengaruh Aliran Kas Bebas Dan Keputusan Pendanaan Terhadap Nilai Pemegang Saham Dengan Set Keputusan Investasi Dan Dividen Sebagai Variabel Mediasi." Jurnal Akuntansi Keuangan 13(1):13-23. Retrieved from https://doi.org/10.9744/jak.13.1.13-23

Astakoni, I. Made Purba, I. Wayan Wardita, and Ni Putu Nursiani (2020). "Ukuran Perusahaan Dan Profitabilitas Sebagai Determinan Nilai Perusahaan Manufaktur Dengan Struktur Modal Sebagai Variabel Mediasi." KRISNA: Kumpulan Riset Akuntansi 12(1):35-49. [9] Basuki, Agus Tri, and Nano Prawoto. 2016. Analisis Regresi Dalam Penelitian Ekonomi Dan Bisnis: Dilengkapi Aplikasi SPSS Dan Eviews. Jakarta: Rajawali Pers Retrieved from https://doi.org/10.22225/kr.12.1.1851.1-6

Budagaga, Akram (2017). "Dividend Payment and Its Impact on the Value of Firms Listed on Istanbul Stock Exchange: A Residual Income Approach." 7(2):370- 


\section{Retrieved from https://www.researchgate.net/profile/Akram- Budagaga- \\ 2/publication/343350075_DIVIDEND_PAYMENT_AND_ITS_IMPACT_ON_T HE_VALUE_OF_FIRMS_LISTED_ON_ISTANBUL_STOCK_EXCHANGE_A_RESID UAL_INCOME_APPROACH/links/5f246a84458515b729f8ab3d/DIVIDEND- PAYMENT-AND-ITS-IMPACT-ON-THE-VALUE-OF-FIRMS-LISTED-ON- ISTANBUL-STOCK-EXCHANGE-A-RESIDUAL-INCOME-APPROACH.pdf}

Fahmi, Irham (2013). Analisis Laporan Keuangan. Bandung: Alfabeta.

Ghozali, Imam (2018). Aplikasi Analisis Multivariate Dengan Program IBM SPSS 25. Semarang: Badan Penerbit Universitas Diponegoro. Retrieved from http://repo.unikadelasalle.ac.id/index.php?p=show_detail\&id=13099

Ghozali, Imam, and Dwi Ratmono (2013). Analisis Multivariat Dan Ekonometrika Teori, Konsep Dan Aplikasi Dengan Eviews 8. Semarang: Universitas Diponegoro.

Gujarati, D.N., (2012), Dasar-dasar Ekonometrika, Terjemahan Mangunsong, R.C., Salemba Empat, buku 2, Edisi 5, Jakarta

Gunawan, I. Made Adi (2018). "The Effect Of Capital Structure, Dividend Policy, Company Size, Profitability And Liquidity On Company Value (Study At Manufacturing Companies Listed On Indonesia Stock Exchange 20142016)." International Journal of Economics, Commerce and Management, United Kingdom VI(6).

Hery (2016). Financial Ratio for Business. Jakarta: PT. Grasindo.

Husain, Saleh (2016). "Industri Makanan dan Minuman RI Tumbuh 8,16\%" http://www.kemenperin.go.id/artikel/12163/Industri-Makanan-danMinuman-RI-Tumbuh-8,16 (diakses tanggal 25 Mei 2021).

Kountur, Roony (2005). Metode Penelitian. Jakarta: PPM. [18] Alenazi, Huda, and Bernard Barbour. 2019. "The Relationship between Dividend Policy and Firm Value within Qatari Banks." Qscience Connect 2019(1):1-22. Retrieved from https://doi.org/10.5339/connect.2019.5

Moeljadi (2014). "Factors Effecting Firm Value." South East Asia Journal of Contemporary Business, Economics and Law 5 No 2:6-15. [20] Alenazi, Huda, and Bernard Barbour. 2019. "The Relationship between Dividend Policy and Firm Value within Qatari Banks." Qscience Connect 2019(1):1-22.

Mulyana, Bambang, and Rahmatika Rini (2017). "Pengaruh Solvabilitas; Profitabilitas; Ukuran Perusahaan Serta Dampaknya Pada Return Saham Perusahaan Sub Sektor Otomotif Dan Komponennya Yang Terdaftar Di Bursa Efek Indonesia Periode Tahun 2010-2016." Jurnal Ilmiah Manajemen \& Bisnis 3(1):17-30.

Salim, M. Noor, and Zaky Firdaus (2020). "Determinants of Firm Value and Its Impact on Stock Prices (Study in Consumer Good Public Companies in Idx 2014-2018)." Dinasti International Journal of Education Management and Social Science 2(1):41-54. Retrieved from https://doi.org/10.31933/dijemss.v2i1.506

Salim, M. Noor, and Rina Susilowati (2020a). "The Effect of Internal Factors on Capital Structure and Its Impact on Firm Value: Empirical Evidence From the Food and Baverages Industry Listed on Indonesian Stock Exchange 20132017." International Journal of Engineering Technologies and Management 


$\begin{array}{lcc}\text { Research 6(7):173-91. } & \text { Retrieved } & \text { from } \\ \text { https://doi.org/10.29121/ijetmr.v6.i7.2019.434 } & \end{array}$

Salim, M. Noor, and Rina Susilowati (2020b). "The Effect of Internal Factors on Capital Structure and Its Impact on Firm Value: Empirical Evidence From the Food and Baverages Industry Listed on Indonesian Stock Exchange 20132017." International Journal of Engineering Technologies and Management Research 6(7):173-91. Retrieved from https://doi.org/10.29121/ijetmr.v6.i7.2019.434

Ulfa, Luluk Mariyah, and Tri Yuniati (2016). "Jurnal Ilmu Dan Riset Manajemen : Volume 5, Nomor 5, Mei 2016 ISSN : 2461-0593 Pengaruh Kinerja Keuangan, Asset Growth Dan Firm Size Terhadap Dividend Payout Ratio." Jurnal Ilmu Dan Riset Manajemen 5(5):1-16. 